\title{
NIEZALEŻNOŚĆ PROKURATURY I PROKURATORÓW - NOWE ROZWIĄZANIA NA TLE DOTYCHCZASOWYCH KONTROWERSJI (UWAGI W ZWIĄZKU Z USTAWĄ Z 28 STYCZNIA 2016 R. - PRAWO O PROKURATURZE'1)
}

\section{NIEZALEŻNOŚĆ PROKURATURY I PROKURATORA - GWARANCJE KONSTYTUCYJNE I STANDARDY EUROPEJSKIE}

Na przestrzeni ostatnich dwudziestu kilku lat, jakie minęły od zakończenia obrad Okragłego Stołu, zagadnienia dotyczące modelu i funkcjonowania prokuratury były stosunkowo często poruszane w mniej lub bardziej obszernych opracowaniach. Atrakcyjność, a zarazem i aktualność tematu wynikała $\mathrm{z}$ jednej strony z potrzeby komentarza podejmowanych przez ustawodawcę istotnych dla ustroju prokuratury ingerencji legislacyjnych. Z drugiej natomiast - stanowiła formę przekazu w kierunku ustawodawcy postulatów de lege ferenda, ważnych z perspektywy funkcjonowania tego organu. Realizacja inicjatyw ustawodawczych w odniesieniu do prokuratury jest bowiem stosunkowo prosta, ponieważ regulujące ją przepisy nie posiadają rangi konstytucyjnej, a więc ich zmiana jest łatwiejsza w porównaniu z procedurą legislacyjna, jaką należy uruchomić w przypadku zmiany Konstytucji².

Warto zasygnalizować równocześnie, że $\mathrm{w}$ toku prac legislacyjnych nad przygotowywaniem obowiązującej Konstytucji z 1997 r. rozważano możliwość

\footnotetext{
${ }^{1}$ Poselski Projekt ustawy - Prawo o prokuraturze wpłyną do Sejmu 24 grudnia 2015 r., a 30 grudnia 2015 r. skierowany został do pierwszego czytania na 8 posiedzeniu Sejmu VIII kadencji. 13 stycznia 2016 r. pisemne stanowisko dotyczące złożonego projektu przedstawiła Rada Ministrów, a 14 stycznia 2016 r. odbyło się pierwsze sejmowe czytanie projektu, który następnie przekazany został Komisji Sprawiedliwości i Praw Człowieka. Po zakończeniu pracy nad projektem 22 stycznia $2016 \mathrm{r}$. Komisja przedstawiła sprawozdanie z przebiegu obrad wraz z załączonym projektem, jaki ostatecznie został wypracowany w jej ramach (druk sejmowy 197). 22 stycznia 2016 r. odbyło się II sejmowe czytanie, po którym projekt ponownie skierowano do Komisji Sprawiedliwości i Praw Człowieka, Komisja odrzuciła wszystkie zgłoszone przez Sejm poprawki. 28 stycznia 2016 r. projekt wrócił pod obrady Sejmu, został uchwalony, a nowo przyjęta ustawa przekazana została Marszałkowi Senatu. Senat przyją ustawę 30 stycznia 2016 r., a 1 lutego 2016 r. przekazano ja Prezydentowi RP do podpisu.

${ }^{2}$ Szerzej: H. Suchocka, W poszukiwaniu modelu ustrojowego prokuratury (w świetle prac Komisji Rady Europy „Demokracja poprzez Prawo”), „Ruch Prawniczy, Ekonomiczny i Socjologiczny” 76, 2014, z. 2, s. 164-166.
} 
ulokowania w ustawie konstytucyjnej regulacji określających pozycję ustrojowa prokuratury i prokuratora, ale ostatecznie zrezygnowano z tego rozwiązania z uwagi na przyjęcie monteskiuszowskiej koncepcji podziału władzy i podporządkowanie prokuratury Radzie Ministrów. Niemniej jeszcze przed przyjęciem Konstytucji z 1997 r., na gruncie Konstytucji z 1952 r., pewne regulacje dotyczące prokuratury o charakterze ustrojowym, pozostające w związku z przyjęciem wspomnianej powyżej koncepcji, zostały w niej umieszczone. Zgodnie z ustawa z 29 grudnia 1989 r. o zmianie Konstytucji Polskiej Rzeczypospolitej Ludowej ${ }^{3} \mathrm{w}$ treści art. 64-66 przyjęto, że prokuratura podlega Ministrowi Sprawiedliwości, który sprawuje funkcję Prokuratora Generalnego, likwidując w ten sposób ówczesną samodzielność Prokuratora Generalnego, podporządkowanego dotychczas Prezydentowi, a uprzednio Radzie Państwa ${ }^{4}$.

W zakresie postanowień regulujących funkcjonowanie prokuratury ostatecznie w Konstytucji RP z 1997 r. nie powtórzono już zapisu o podporządkowaniu prokuratury Ministrowi Sprawiedliwości, a jedynie w rozdziale VIII: „Sądy i Trybunały” znalazły się postanowienia dotyczące Prokuratora Generalnego, w których przyznano mu kompetencję do inicjowania postępowania przed Trybunałem Konstytucyjnym i uczestnictwa we wszystkich postępowaniach przed tym Trybunałem (art. 191 ust. 1). Na poziomie postanowień konstytucyjnych określone zostały też uprawnienia Prezesa Rady Ministrów wobec Prokuratora Generalnego z treści art. 146 ust. 4 pkt 7 w powiązaniu z art. 148 ust. 4 wynika, że Rada Ministrów zapewnia bezpieczeństwo wewnętrzne państwa oraz porządek publiczny, a Prezes Rady Ministrów zapewnia wykonywanie polityki Rady Ministrów. Co odpowiednio uzupełniają postanowienia ustawy o prokuraturze, w wersji po nowelizacji z 2009 r. ${ }^{5}$ zobowiąujace Prokuratora Generalnego do przedstawiania Prezesowi Rady Ministrów sprawozdań z rocznej działalności prokuratury, które to sprawozdanie Prezes Rady Ministrów przyjmuje lub odrzuca. W razie odrzucenia sprawozdania premier może zwrócić się do Sejmu o odwołanie Prokuratora Generalnego przed upływem jego kadencji, po uprzednim zasięgnięciu opinii Krajowej Rady Prokuratorów. Prokurator Generalny zobowiązany jest także do przedstawienia informacji na określony temat związany ze strzeżeniem praworządności oraz

\footnotetext{
3 Dz. U. 1989, Nr 75, poz. 44.

${ }^{4}$ W literaturze zwraca się uwagę, że decyzja o podporządkowaniu prokuratury Ministrowi Sprawiedliwości poza uzasadnieniem teoretycznoprawnym uwzględniała też ówczesną sytuację społeczno-polityczna, w której jednym z celów politycznych było wyłączenie prokuratury spod nadzoru i wpływu prezydenta, którym ówcześnie był gen. Wojciech Jaruzelski (za: A. Herzog, Niezależność prokuratury - mit czy nadzieja?, „Prokuratura i Prawo” 2009, z. 1, s. 113), nadto decyzję tę traktowano jako symboliczne zerwanie z prokuraturą funkcjonując w okresie PRL (za: J. Kędzierski, O niezależność prokuratury - w kręgu faktów i mitów, „Prokuratura i Prawo” 2009, z. 1, s. 105-106), której niezależność miała jedynie iluzoryczny charakter, głównie z powodu powszechnie akceptowanego założenia kierowniczej roli PZPR, partia bowiem swoim wpływem determinowała wszystkie elementy działalności państwa i jego organów (szerzej J. Smoleński, Rodowód leninowskiej koncepcji prokuratury $i$ jej ustawowa realizacja, „Problemy Praworządności” 1970, z. 7/8, s. 21).

5 Ustawa z 9 października 2009 r. o zmianie ustawy o prokuraturze oraz niektórych innych ustaw, Dz. U. 2009, Nr 178, poz. 1375.
} 
czuwaniem nad ściganiem przestępstw, jeżeli Prezes Rady Ministrów takich informacji zażąda (art. 10e ustawy o prokuraturze).

Trzeba jednak podkreślić, że usytuowanie postanowień dotyczących ustroju prokuratury poza obszarem Konstytucji RP nie narusza standardów wynikajacych z członkostwa Polski w organizacjach międzynarodowych i przyjętych w konsekwencji członkostwa zobowiązań międzynarodowych. Dokumenty, jakie w tym przedmiocie zostały przedstawione przede wszystkim przez Komitet Ministrów Rady Europy, mają formę rekomendacji, a więc pozastawiają państwu znaczną elastyczność w zakresie ich wykorzystania ${ }^{6}$. Omawiając kryterium niezależności w świetle działalności Komisji Weneckiej, Hanna Suchocka zwróciła uwagę, że przygotowane przez Komisję wytyczne, też nie formułuja jednoznacznie sposobu organizacji funkcjonowania prokuratury, ale wskazują gwarancje, które powinny zostać uwzględnione przy konstruowaniu modelu organizacyjnego prokuratury. Odwołując się bezpośrednio do przygotowanych dokumentów, podkreśliła, że w świetle standardów europejskich sprzyjających zapewnieniu niezależności prokuratorskiej w pierwszej kolejności pożądane jest zapewnienie granicy wewnętrznej i zewnętrznej tej niezależności przez przyjęcie instrumentów, które powstrzymają rząd od ingerencji w poszczególne sprawy oraz uniemożliwią wpływanie na decyzje prokuratora przez inne osoby w obrębie prokuratury, także w sytuacji, wydzielenia prokuratury ${ }^{7}$. Równocześnie trzeba zauważyć, że Komisja Wenecka dostrzegła problemy, jakie dla pojęcia niezależności prokuratorskiej stwarza synchronizowana $\mathrm{z}$ nią jedna z zasad ustrojowych prokuratury, która stanowi zasada hierarchiczności - dlatego też postulowała określenie gwarancji przysługujących prokuratorowi, w stosunku do którego kierowane są instrukcje przełożonych, przypominajac w tym zakresie rekomendacje Komitetu Ministrów Rady Europy, w których wyraźnie zalecono, aby instrukcje takie posiadały formę pisemna, a przyjęte procedury gwarantowały prokuratorowi możliwość zastąpienia go przez inną osobę, jeżeli według jego oceny instrukcja jest niezgodna z prawem lub przeciwna jego przekonaniu ${ }^{8}$.

Według Komisji Weneckiej, jak referuje Hanna Suchocka, ocena modelu prokuratury w związku z realizacją postulatu niezależności obejmuje też:

- sposób powoływania prokuratora generalnego, Komisja także i w tej kwestii nie proponuje konkretnych rozwiązań, ale wyraźnie zaleca współpracę różnych organów państwowych w zakresie jego powołania, aby w ten sposób

\footnotetext{
${ }^{6}$ Uwzględnienia w tym kontekście wymagaja: - Recommendation Rec(2000)19 of the Committee of Minister of the Council of Europe on the Role of Public Prosecution in the Criminal Justice System; - The 1990 United Nations Guidelines on the Role of Prosecutors; - The1999 IAP (International Association of Prosecutors) Standards of Professional Responsibility and Statement of the Essential Duties and Rights of Prosecutors; - The Bordeaux Declaration of the Consultative Council of European Judges (CCJE) and the Consultative Council of European Prosecutors (CCPE) on „Judges and Prosecutors in a Democratic Society”; - The European Guidelines on Ethics and Conduct for Public Prosecutors (Council of Europe, „Budapest Guidelines”, 2005); - European Standards as regards the Independence of the Judicial System, part II - the prosecution service (CDL- $\mathrm{AD}(2010) 040)$.

${ }^{7}$ Za: H. Suchocka, op. cit., s. 170.

${ }^{8}$ Recommendation Rec(2000)19 of the Committee of Minister of the Council of Europe on the Role of Public Prosecution in the Criminal Justice System.
} 
uniknąć nominacji politycznych, za akt polityczny uważa też powołanie prokuratora generalnego przez parlament; zdaniem Komisji Weneckiej w procedurze powoływania prokuratora generalnego dużą rolę powinna odgrywać Rada Prokuratorów, a sama kadencja prokuratora generalnego powinna być stosunkowo długa, bez możliwości ponownego ubiegania się o to stanowisko;

- obowiązywanie zasady odpowiedzialności, przyznana prokuraturze niezależność w racjonalnej ocenie Komisji Weneckiej nie może mieć charakteru zupełnie niekontrolowanego, dlatego też Komisja opowiada się za koniecznością sporządzania przez prokuratora generalnego rocznych sprawozdań z jego działalności przedstawianych rządowi lub parlamentowi; w sprawozdaniach powinny być umieszczona informacja o instrukcjach, jakie zostały przekazane prokuratorowi do realizacji przez rząd, z uwzględnieniem przyjętych priorytetów;

- określenie zakresu władzy prokuratora, zalecenie to Komisja kieruje szczególnie wobec państw młodych demokracji, które uwolniły się od wpływu politycznego Związku Radzieckiego, a w których mogą pojawić się tendencje do nadmiernego rozszerzenia władzy prokuratora, którego działalność skoncentrowana powinna być przede wszystkim wokół postępowań karnych, pozostawiając inne zagadnienia w szczególności związane z ochroną praw człowieka, weryfikacji prawomocnych orzeczeń sądowych innym właściwym organom funkcjonującym w ramach demokratycznego państwa ${ }^{9}$.

Funkcjonowanie prokuratury od 1985 r. regulowała - zmieniana kilkadziesiąt razy - ustawa o prokuraturze. W środowisku prokuratorskim, jak i wśród teoretyków prawa co pewien czas odżywał postulat przygotowania nowej ustawy, jednakże nawet w okresie po wejściu w życie Konstytucji z 1997 r. nie doszło do jej finalnego opracowania, choć być może był to stosunkowo najbardziej dogodny czas dla podjęcia takiej inicjatywy.

Do czasu przyjęcia w 2009 r. nowelizacji ustawy o prokuraturze ${ }^{10}$, głównym przepisem dla prezentacji atrybutu niezależności prokuratorskiej był art. 8 ust. 1, z którego treści wynikało, że prokurator przy wykonywaniu czynności określonych w ustawach jest niezależny, ale z zastrzeżeniem wskazanych przepisów, tj. ust. 2-4 art. 8, według których prokurator był obowiąany wykonywać zarządzenia, wytyczne i polecenia przełożonego prokuratora, z zastrzeżeniem, że wydawane są one przez przełożonego na piśmie, a na pisemne uzasadnione żądanie prokuratora wraz z uzasadnieniem. Natomiast w przypadku, gdy prokurator nie zgadzał się z poleceniem, mógł wystapić z pisemnym wnioskiem o zmianę kwestionowanego polecenia lub wyłączenie go od wykonania kwestionowanej czynności. Przyjęto przy tym założenie, że polecenie takie wydane przez przełożonego innego niż bezpośredni nie może obejmować sposobu zakończenia postępowania przygotowawczego i postępowania przed sądem (ust. 5 art. 8), co a contrario pozwalało na wydanie takiego polecenia przez bezpośrednio przełożonego. Dopatrując się ograniczenia niezależności prokuratora w zakresie samodzielności decyzyjnej, komentatorzy podnosili

9 Por. H. Suchocka, op. cit., s. 170-173.

10 Ustawa z 9 października 2009 r. o zmianie ustawy o prokuraturze oraz niektórych innych ustaw, Dz. U. 2009, Nr 178, poz. 1375. 
zarzut, że ustawa nie wyłącza tzw. łańcuszka poleceń, co de facto prowadziło do sytuacji, że możliwe było wykonanie polecenia prokuratora bezpośrednio przełożonego nad prokuratorem bezpośrednio przełożonym wobec prokuratora, któremu czynność została polecona, co wynikało z treści art. 17a ustawy o prokuraturze. Przepisy ustawy w zakresie wnikania w treść konkretnych czynności procesowych w drodze zarządzeń, wytycznych i poleceń ograniczały jedynie Prokuratora Generalnego (art. 10 ust. 2 ustawy o prokuraturze), który z kolei niestety podejmował próby ich pominięcia ${ }^{11}$. Na gruncie ówczesnego stanu prawnego pełna niezależność zachowywał w zasadzie prokurator w toku postępowania przed sądem, gdy ujawniły się nowe fakty lub dowody, gdyż zgodnie z ustawą mógł samodzielnie podjać decyzję co do dalszego postępowania, a podjęte decyzje posiadały stanowczy charakter, chociaż niestety i w takich przypadkach w praktyce dla bezpieczeństwa zawodowego przed podjęciem decyzji prokurator konsultował się ze swoim bezpośrednim przełożonym. Obowiąujący ówcześnie stan prawny częściowo zatem tylko zbieżny był z zalecanymi standardami europejskimi, w związku z czym dużą aprobatę zyskał postulat zmiany ustawy o prokuraturze w kierunku niezależności, z którą wiązała się również stabilizacja codziennej pracy prokuratora.

\section{NOWELIZACJA Z 2009 R.}

Próbą przybliżenia prokuratury ku niezależności było przyjęcie nowelizacji ustawy o prokuraturze w październiku 2009 r. W ramach wprowadzonych zmian uwzględniono rekomendacje Komitetu Ministrów Rady Europy oraz formułowane ogólnie zalecenia Komisji Weneckiej, co mając na uwadze, można było stwierdzić, że ukształtowany model prokuratury pozwalał na jej funkcjonowanie w sposób niezależny zarówno od władzy wykonawczej, jak i ustawodawczej. W nurcie pierwszoplanowych zmian gwarantujacych niezależność ustrojową prokuratury wskazać należy przede wszystkim na rozdzielenie funkcji Prokuratora Generalnego i Ministra Sprawiedliwości, w wyniku czego Prokurator Generalny uznany został za naczelny organ Prokuratury, a Prokuratura za organ ochrony prawnej (art. 1 ust. 2 i 3 ustawy o prokuraturze w wersji po nowelizacji z 2009 r.). Zakończenie unii personalnej między Prokuratorem Generalnym a Ministrem Sprawiedliwości spotkało się także z krytyczną ocena. Przeciwnicy przyjętego ówcześnie rozwiązania podnosili, iż jest ono niezgodne z przyjętym w art. 146 ust. 4 pkt 7 Konstytucji RP (wspomnianym już wyżej) rozwiązaniem, gdyż przez zerwanie unii personalnej rząd traci wpływ na prokuraturę, co uniemożliwia mu zapewnienie bezpieczeństwa wewnętrznego państwa i porządku publicznego. Nadto wskazywano również, że w wyniku rozdzielenia funkcji Ministra Sprawiedliwości i Prokuratora Gene-

\footnotetext{
11 Ograniczenie to nie było jednak w sposób bezwzględny przestrzegane, a jako przykład jego naruszenia przytaczano decyzje podjęte przez Prokuratora Generalnego dotyczące stosowania środków zapobiegawczych w tzw. sprawie we Włodawie, por. T. Grzegorczyk, Niezależność prokuratury i prokuratorów w świetle znowelizowanej ustawa z dnia 9 października 2009 roku ustawy o prokuraturze, „Prokuratura i Prawo” 2010, z. 1/2, s. 28.
} 
ralnego może nastapić alienacja prokuratury ze struktury organów państwa, przez co stanie się ona niekontrolowanym organem o wielkich możliwościach ścigania przestępstw i inwigilowania oraz ingerowania w prawa i wolności obywatelskie ${ }^{12}$. Podnoszony argument należało uznać za nietrafny przede wszystkim z uwagi na mocno zakorzenioną już w polskim procesie karnym możliwość sądowej kontroli decyzji prokuratorskich oraz wyraźne określenie czynności, które w stadium postępowania przygotowawczego zastrzeżone zostały do właściwości sądu, a przed wszczęciem tego postępowania dla swej legalności wymagały zgody sądu.

Nowelizacja zniosła też Prokuraturę Krajowa, a powołała Prokuraturę Generalna (art. 17 ustawy z 9 października 2009 r.). Według przyjętego rozwiązania Prokurator Generalny powoływany miał być na sześcioletnią kadencję przez Prezydenta RP, spośród dwóch kandydatów przedstawianych po jednym przez Krajowa Radę Sądownictwa i Krajową Radę Prokuratury. Z uwagi jednak na fakt, że Krajowa Rada Prokuratury przy powoływaniu pierwszego Prokuratora Generalnego w oparciu o nowo przyjęte rozwiązanie nie była jeszcze ustanowiona, dlatego też przedstawiony został tylko jeden kandydat proponowany przez Krajową Radę Sądownictwa (art. 18 ustawy z 9 października 2009 r.). W kontekście działań podejmowanych w kierunku zwiększenia niezależności prokuratury, łączonych również z zamiarem jej odpolitycznienia, duże znaczenie posiadało skonkretyzowanie wymogów, jakie spełniać musi osoba ubiegająca się o stanowisko Prokuratora Generalnego. Chcąc uniknąć kandydatów politycznych, przyjęto kryteria dotyczące życia zawodowego kandydata. Zgodnie z przyjętym ówcześnie art. 10a ust. 3 ustawy o prokuraturze o stanowisko Prokuratora Generalnego mogła ubiegać się osoba, będąca prokuratorem w stanie czynnym lub sędzią w stanie czynnym, w tym także sędzią Izby Karnej lub Wojskowej Sądu Najwyższego, posiadająca co najmniej dziesięcioletni staż odpowiednio na stanowisku prokuratora lub sędziego, z tym że ten ostatni z wymienionych musiałby orzekać w sprawach karnych. Nie ulega wątpliwości, że weryfikacja kandydata pod kątem oceny sprawowania przez niego wieloletniej służby na stanowisku sędziego lub prokuratora gwarantowała, że stanowisko Prokuratora Generalnego przejmuje osoba o mocnym kręgosłupie moralnym, nieulegająca jakimkolwiek wpływom i naciskom. W tym kontekście warto podkreślić, że w przyjętym rozwiązaniu Prokurator Generalny wskazuje również swoich zastępców, wybierając kandydatów spośród prokuratorów Prokuratury Generalnej, Naczelnej Prokuratury Wojskowej i IPN, którzy następnie na jego wniosek są powoływani przez Prezydenta RP (art. 12 ust. 1-3 ustawy o prokuraturze w wersji przyjętej w 2009 r.). Także i w tym przypadku, wybierając najbliższych współpracowników, Prokurator Generalny uzyskał możliwość wzmocnienia swej niezależnej pozycji. Z kolei przyjęty sześcioletni okres kadencji Prokuratora Generalnego pozwalał kierować powierzonym mu organem w sposób stabilny z odpowiednią możliwością zaplanowania realizacji wytyczonych celów i przyjmowanych priorytetów. Oczywiście dla zwiększenia efektywności funkcjonowania prokuratury nieba-

12 Por. W. Grzeszczyk, Nowy model ustrojowy prokuratury, „Prokuratura i Prawo” 2010, z. 3, 7-8. 
gatelne znaczenie posiadał też dobry kontakt Prokuratora Generalnego z Prezesem Rady Ministrów oraz Ministrem Sprawiedliwości, chociażby z uwagi na konieczność wspólnych uzgodnień np. w zakresie przyjmowania aktów wykonawczych, których wydanie pozostało w gestii Ministra Sprawiedliwości, czy tė̇ prowadzenia współpracy w związku z działalnością Krajowej Szkoły Sądownictwa i Prokuratury.

Uzyskana przez Prokuraturę niezależność - jak już na wstępie niniejszego opracowania wspomniano - nie posiadała charakteru nieograniczonego, ale podlegała kontroli poprzez obowiązek składania corocznych sprawozdań na ręce Prezesa Rady Ministrów, który w razie odrzucenia przedłożonego sprawozdania mógł wystapić do Sejmu o odwołanie Prokuratora Generalnego przed upływem kadencji, zasięgając uprzednio opinii Krajowej Rady Prokuratorów, która powinna zostać załączona do wniosku (art. 10e ust. 1, 6 i 7 ustawy o prokuraturze w wersji z 2009 r.). W komentarzach przyjętego rozwiązania podnoszono, iż mocno narusza ono niezależność prokuratury i pozwala Prezesowi Rady Ministrów doprowadzić do utraty stanowiska przez Prokuratora Generalnego, który jest negatywnie przez niego oceniany. W tym zakresie niewatpliwie widoczny jest brak wskazania ustawowych kryteriów, na podstawie których Prezes Rady Ministrów weryfikuje sprawozdanie Prokuratora Generalnego, a w konsekwencji decyduje o odrzuceniu corocznego sprawozdania z działalności prokuratury ${ }^{13}$. Należy jednak zauważyć, że możliwość usunięcia Prokuratora Generalnego oparta wyłącznie na niechęci Prezesa Rady Ministrów została mocno ograniczona nie tylko przez konieczność uzyskania opinii Krajowej Rady Prokuratury, lecz także przyjęcie zapisu, że odwołanie może nastapić tylko kwalifikowaną większością głosów 2/3, w obecności co najmniej połowy ustawowej liczby posłów.

Ponadto Prezes Rady Ministrów może w każdym czasie żądać od Prokuratora Generalnego informacji na określony temat związany ze strzeżeniem praworządności i czuwaniem nad ściganiem przestępstw, przy czym żądanie to nie może dotyczyć informacji o biegu postępowania w konkretnej sprawie (art. 10e ust. 3 ustawy o prokuraturze w wersji z 2009 r.). W efekcie przyjęte rozwiązanie wyłącza możliwość legalnego oddziaływania władzy wykonawczej na działania prokuratury w konkretnych sprawach.

Istotnym elementem sprzyjającym utrzymaniu niezależności prokuratorskiej przyjętym w wyniku nowelizacji z 2009 r. są rozwiązania dotyczące wykonywania przez prokuratorów ustawowo przewidzianych czynności. O ile bowiem utrzymany została reguła, że prokurator jest obowiązany wykonywać zarządzenia, wytyczne i polecenia przełożonego prokuratora, co stanowi konsekwencję obowiązywania zasady hierarchicznego postępowania, o tyle jednak przyjęto zastrzeżenie, że wspomniane zarządzenia, wytyczne i plecenia nie mogą dotyczyć czynności procesowych (art. 8 ust. 2 ustawy o prokuraturze w wersji z 2009 r.). Ograniczeniem tym objęte zostały także zarządzenia, wytyczne i polecenia Prokuratora Generalnego (art. 10 ust. 1 i 2 ustawy o prokuraturze w wersji z 2009 r.). Zmieniono wówczas także w kierunku zagwa-

${ }_{13}$ Szerzej B. Mik, Nowe gwarancje niezależności prokuratury i prokuratorów - fakt, czy iluzja, „Prokuratura i Prawo” 2010, z. 5, s. 113. 
rantowania niezależności przepis art. 8a ust. 1 ustawy o prokuraturze przez przyjęcie, że zmiana lub uchylenie decyzji prokuratora podległego może nastapić wyłącznie wskutek interwencji prokuratora bezpośrednio przełożonego, przy czym decyzja to musi mieć formę pisemną i włączona zostaje do akt sprawy. Równocześnie nie uległ zmianie art. 8b ustawy o prokuraturze, zgodnie z którym prokurator przełożony może czynności należące do jego zakresu, powierzyć do wykonania prokuratorowi podwładnemu, jeżeli ustawa nie zastrzega, że czynność ta należy do właściwości prokuratora przełożonego oraz przejąc do prowadzenia sprawy lub czynności prowadzone przez prokuratora podległego, chyba że ustawa stanowi inaczej.

Oceniajac wprowadzone w 2009 r. w obrębie ustawy o prokuraturze zmiany, w miarę zgodnie podkreślano, że stanowią one dobrze wypracowany kompromis między zachowaniem podstawowych dla funkcjonowania prokuratury zasad jednolitości, hierarchicznego podporządkowania, substytucji i dewolucji a niezależnością prokuratorów w prowadzonych przez nich działaniach ${ }^{14}$. Rozwiązania te sprzyjały także zachowaniu niezależności prokuratury jako całości przez ograniczenie możliwości ingerencji władzy wykonawczej w prowadzone postępowania, a nawet uzyskiwania w tym zakresie stosownych informacji.

\section{PRAWO O PROKURATURZE Z 2016 R.}

Potrzeba przyjęcia nowej ustawy regulującej ustrój i funkcjonowanie prokuratury - zważywszy na pozytywną ocenę zmian wprowadzonych nowelizacją z 2009 r. - niewatpliwie może rodzić pewne zaskoczenie, tym bardziej że potrzeba zmiany nie została zaprezentowana na tyle wcześnie, aby mogła łączyć się z nią możliwość uruchomienia konsultacji społecznych i środowiskowych w celu przedyskutowania potrzeby i kierunku wprowadzenia nowych rozwiązań. W świetle poczynionych wyżej uwag trudno zgodzić się z otwierającym uzasadnienie projektu ustawy Prawo o prokuraturze stwierdzeniem, dotyczącym dotychczas obowiązującej ustawy o prokuraturze, że „[...] w chwili obecnej nie spełnia potrzeb nowoczesnego państwa prawa oraz wyzwań związanych z rozwojem technologii i różnego rodzaju przestępczości [...]"15.

Analizując treść proponowanych rozwiązań z punkt widzenia zachowania niezależności prokuratora, przede wszystkim należy zauważyć, że ponownie utworzona została unia personalna między Ministrem Sprawiedliwości i Prokuratorem Generalnym, w związku z czym nastapił powrót do obowiązującej do roku 2009 koncepcji podporządkowania prokuratury władzy wykonawczej. Zgodnie z treścią art. 1 § 2 Prawa o prokuraturze Prokurator Generalny jest naczelnym organem prokuratury, a urząd ten sprawuje Minister Sprawiedliwości. Zasadność przyjęcia wskazanej zmiany uzasadniona została z jednej strony przez podnoszona już przy nowelizacji z 2009 r. - ale krytycznie ocenioną przez środowisko prokuratorskie - interpretacją obowiązywania wspomi-

\footnotetext{
14 T. Grzegorczyk, op. cit., s. 37.

15 Druk 162, Prawo o prokuraturze, uzasadnienie, s. 88.
} 
nanego już powyżej art. 146 ust. 4 pkt 7 Konstytucji RP, przez stwierdzenie, że możliwość zapewnienia bezpieczeństwa wewnętrznego i porządku publicznego, realna może być tylko przy bezpośrednim oddziaływaniu Ministra Sprawiedliwości na funkcjonowanie prokuratury, co można osiagnąć tylko przez reaktywację unii personalnej między Ministrem Sprawiedliwości i Prokuratorem Generalnym. Z drugiej natomiast strony uznano, że połączenie urzędu Ministra Sprawiedliwości i Prokuratora Generalnego doprowadzi do odzyskania przez osobę kierująca prokuraturę „silnej pozycji, zarówno wobec podległych prokuratorów, jak i organów zewnętrznych, a taki stan rzeczy stanowi niezbędny element właściwej realizacji zadań nałożonych przez ustawodawcę na tę instytucję"16. W efekcie zmienione zostały też warunki, jakie powinien spełniać kandydat na stanowisko Prokuratora Generalnego, wypracowane w celu odpolitycznienia tegoż urzędu, skoncentrowane - jak wspomniano - powyżej na perspektywicznej możliwości wykorzystania posiadanego przez kandydata doświadczenia zawodowego do prawidłowego funkcjonowania prokuratury, na rzecz właściwości, jakimi dysponować powinna osoba powoływana na stanowisko Ministra Sprawiedliwości. Warunki, jakim odpowiadać powinna osoba powoływana na urząd Prokuratora Generalnego przy równoczesnym zajmowaniu stanowiska Ministra Sprawiedliwości, precyzuje powołany już częściowo art. $1 \S 2 \mathrm{w}$ związku z art. $75 \S 1$ pkt 1-3 i 8 Prawa o prokuraturze.

$\mathrm{Na}$ gruncie nowo przyjętej ustawy Prawo o prokuraturze Prokuratorem Generalnym może zostać zatem osoba, która: posiada wyłącznie obywatelstwo polskie i korzysta z pełni praw cywilnych i obywatelskich, nie była karana prawomocnie za umyślne przestępstwo ścigane z oskarżenia publicznego, jest nieskazitelnego charakteru, ukończyła wyższe studia prawnicze w Polsce i uzyskała tytuł magistra lub ukończyła zagraniczne studia prawnicze uznane w Polsce oraz nie pełniła służby zawodowej, nie pracowała lub nie była współpracownikiem organów bezpieczeństwa państwa wymienionych w art. 5 ustawy z 18 grudnia 1998 r. o Instytucie Pamięci Narodowej - Komisji Ścigania Zbrodni Przeciwko Narodowi Polskiemu ${ }^{17}$, ani też nie była sędzia, który orzekając, uchybił godności urzędu sprzeniewierzając się niezawisłości sędziowskiej, co zostało stwierdzone prawomocnym orzeczeniem. Wyeliminowane zostały zatem warunki, uznane za szczególnie wartościowe według kryteriów przyjętych w 2009 r., związane z doświadczeniem zawodowym uzyskanym poprzez czynne, obejmujące co najmniej dekadę pełnienie służby sędziowskiej lub prokuratorskiej.

W związku z nowo przyjętymi rozwiązaniami zmianie uległ także sposób powoływania zastępców Prokuratora Generalnego, którzy powoływani są przez Prezesa Rady Ministrów na wniosek Prokuratora Generalnego, po uprzednim uzyskaniu opinii Prezydenta PR. Wskazana procedura powołania obejmuje również Prokuratora Krajowego (art. 14 § 1 Prawa o prokuraturze). Zwraca uwage, że w obu przypadkach w procedurze powołania pominięta została rola Krajowej Rady Prokuratorów, która w świetle postanowień ustawy o prokuraturze w wersji po nowelizacji z 2009 r. miała stanowić jeden z gwarantów

16 Druk 162, Prawo o prokuraturze, uzasadnienie, s. 88.

17 Dz. U. 2014, poz. 1075 ze zm. 
niezależności prokuratora i prokuratury. W niniejszym kontekście podkreślenia wymaga też zmiana warunków, jakie spełniać powinni kandydaci na stanowisko zastępcy Prokuratora Generalnego. Ustawa o prokuraturze w wersji od października 2009 r. kładła mocny akcent na konieczność powoływania na wymienione wyżej stanowiska osób związanych zawodowo z pełnieniem służby sędziowskiej lub prokuratorskiej, przyjmowana obecnie ustawa rozszczelnia obowiązujacy dotychczas system, dopuszczając też powołanie osób wykonujących inne zawody prawnicze, tj. adwokata, radcy prawnego, notariusza - przy uwzględnieniu progu w wysokości 12 lat wykonywania wymienionych zawodów.

W zakresie organizacji prokuratury, a w szczególności zajmowania stanowisk funkcyjnych i kierowniczych, których sprawowanie również łączy się z kwestią niezależności, należy wskazać, że nowo przyjęta ustawa rezygnuje z ich dotychczasowej kadencyjności, pozwalając Prokuratorowi Generalnemu i Prokuratorowi Krajowemu na prowadzenie „swobodnej, ograniczonej tylko ustawą polityki kadrowej"18.

Natomiast dla oceny niezależności prokuratora w zakresie wewnętrznych regulacji dotyczących stosunków na linii przełożony-podwładny, w świetle Prawa o prokuraturze kluczową rolę grają rozwiązania przyjęte w art. 7, a zwłaszcza w treści jego § 3 i 4 .

Przepis art. $7 \S 1$ stanowi, że prokurator przy wykonywaniu czynności określonych w ustawach jest niezależny, a ograniczenie niezależności określone jest przez ustawę. Prokurator zatem jest obowiązany wykonywać zarządzenia, wytyczne i polecenia przełożonego prokuratora ( $(2)$. W tym zakresie powtórzono uprzednio obowiązujące już rozwiązania. Nowe regulacje pojawiają się jak już wspomniano w treści $§ 3$ i 4 art. 7 Prawa o prokuraturze. Otóż zgodnie z treścią $\S 3$ polecenia dotyczące czynności procesowej prokurator przełożony wydaje na piśmie, na żądanie prokuratora wraz z uzasadnieniem, w razie jednak przeszkody w doręczeniu polecenia w formie pisemnej dopuszczalne jest przekazanie polecenia ustnie, z tym że przełożony jest obowiązany niezwłocznie potwierdzić polecenie na piśmie, w obu przypadkach polecenia włącza się do akt sprawy. Wyeliminowany został więc zakaz wydawania poleceń dotyczących czynności procesowych, co znacznie ograniczyło zakres niezależności prokuratora i umożliwiło ingerencję w konkretne sprawy. Trzeba też podkreślić, że treść przepisu nie precyzuje przełożonego, który został uprawniony do wydawania poleceń, a więc może to uczynić nie tylko bezpośrednio przełożony, ale każdy z przełożonych, na co wyraźnie wskazuje zapis art. 34 § 1 i 2 Prawa o prokuraturze ${ }^{19}$, w efekcie znów pojawiła się możliwość wydawania tzw. po-

18 Druk 162, Prawo o prokuraturze, uzasadnienie, s. 93.

${ }_{19}$ Według przywołanego przepisu prawo wydawania poleceń przyznano w treści $§ 1$ : dyrektorom departamentów Prokuratury Krajowej w stosunku do prokuratorów pełniących czynności w departamentach oraz prokuratorów regionalnych, okręgowych i rejonowych (pkt 1); naczelnikom wydziałów w departamentach Prokuratury Krajowej w stosunku do prokuratorów pełniących czynności w tych wydziałach (pkt 2); naczelnikom wydziałów i kierownikom działów oraz samodzielnych działów prokuratur regionalnych w stosunku do prokuratorów pełniących czynności w tych wydziałach, działach i samodzielnych działach oraz prokuratorów okręgowych i rejonowych: naczelnikom wydziałów oraz kierownikom działów, samodzielnych działów i ośrodków 
leceń łańcuszkowych. Ponadto w niniejszym kontekście trzeba też uwzględnić przepis art. $13 \S 1$ Prawa o prokuraturze, zgodnie z którym możliwość wydawania zarządzeń, wytycznych i poleceń przyznana została również Prokuratorowi Generalnemu.

W obronie niezależności prokuratora wskazać należy na możliwość sprzeciwienia się przez prokuratora poleceniu, o czym stanowi przepis $\S 4$ art. 7 Prawa o prokuraturze, zgodnie z którym gdy prokurator nie zgadza się z poleceniem dotyczącym treści czynności procesowej, może żądać zmiany polecenia lub wyłączenia go od wykonania czynności albo od udziału w sprawie, przy czym przyjęto, że o wyłączeniu rozstrzyga prokurator bezpośrednio przełożony nad prokuratorem, który wydał polecenie. Żądanie zmiany polecenia lub wyłączenia od dokonania czynności prokurator zgłasza na piśmie wraz z uzasadnieniem przełożonemu, który wydał polecenie (art. 7 § 5 Prawa o prokuraturze).

Wprowadzone w treści $§ 4$ rozwiązanie budzi jednak wątpliwości, gdyż wynika z niego, że w razie żądania prokuratora o wyłączenie od wykonania czynności decyzję w przedmiocie wniosku podejmuje prokurator bezpośrednio przełożony nad prokuratorem, który wydał polecenie, przepis nie wskazuje natomiast, kto jest kompetentny do rozstrzygnięcia wniosku w przypadku, gdy prokurator będzie żądał zmiany wydanego mu polecenia. Poza tym w ogóle trudno wskazać procedurę możliwości zmiany polecenia w sytuacji wydania go przez Prokuratora Generalnego, który przecież znajduje się na szczycie hierarchicznej drabiny. Brak w tym przedmiocie jednoznacznych reguł rozstrzygnięcia sporu może w rezultacie spowodować, że prokurator zostanie zmuszony do wykonania polecenia, mimo żądania zmiany polecenia, sytuacja ta budzi niepokój środowiska prokuratorskiego, jako naruszająca niezależność prokuratora, co jednoznacznie podkreślił Prokurator Generalny w opinii uzupełniającej do poselskich projektów ustawy Prawo o prokuraturze ${ }^{20}$.

Z kolei w art. 7 § 6 Prawa o prokuraturze zachowana została możliwość podjęcia przez prokuratora samodzielnej decyzji związanej z dalszym tokiem postępowania, gdy w trakcie postępowania sądowego ujawnia się nowe okoliczności, jednakże wyłączono możliwość samodzielnego rozstrzygnięcia, jeżeli następstwem decyzji prokuratora byłaby konieczność dokonania wydatku przewyższającego kwotę ustaloną przez kierownika jednostki organizacyjnej. Wówczas podjęcie przez prokuratora decyzji co do dalszego postępowania uzależnione jest od uzyskania zgody kierownika jednostki organizacyjnej. Wypada jednak zauważyć, że w sytuacji, w której zachodzi konieczność podjęcia decyzji związanej z dalszym tokiem postępowania, prokuratorzy także i na

\footnotetext{
zamiejscowych prokuratur okręgowych, w stosunku do prokuratorów pełniących czynności w tych wydziałach, działach, samodzielnych działach i ośrodkach zamiejscowych oraz prokuratorów rejonowych (pkt 4); kierownikom ośrodków zamiejscowych prokuratur rejonowych w stosunku do prokuratorów pełniących czynności w tych ośrodkach (pkt 5); przy czym przepisy pkt 1 i 2 stosuje się odpowiednio do zastępców dyrektorów departamentów Prokuratury Krajowej i zastępców naczelników wydziałów w departamentach Prokuratury Krajowej (§ 2).

${ }^{20}$ Zob. Opinia uzupełniająca Prokuratora Generalnego do poselskich projektów ustawy - Prawo o prokuraturze (druk sejmowy 162 i 162-A) oraz ustawy Przepisy wprowadzające ustawę Prawo o prokuraturze (druk sejmowy 163), dostępna na: www.pg.gov.pl [dostęp: 17.02.2016].
} 
gruncie poprzednio obowiąujących regulacji przed podjęciem decyzji konsultowali się ze swoimi przełożonymi, co szczególnie widoczne było i jest w sprawach, w których dochodzi do skorzystania przez oskarżonego na rozprawie z instytucji dobrowolnego poddania się karze (art. 387 k.p.k.).

Aby ocenić poziom niezależności prokuratora kształtowanego w oparciu o rozwiązania zawarte $\mathrm{w}$ ustawie Prawo o prokuraturze, należy także uwzględnić art. $8 \S 1$ omawianej ustawy, zgodnie z którym prokurator przełożony uprawniony jest do zmiany lub uchylenia decyzji prokuratora podległego. Zmiana wymaga formy pisemnej i załączana jest do akt sprawy (§ 2), co odczytane być musi jako kolejny przejaw ograniczenia niezależności prokuratora.

W zakresie niezależności prokuratora, a także i zasady domniemania niewinności duże wątpliwości budzi przepis art. 12 Prawa o prokuraturze, a zwłaszcza treść jego § 2, w którym przyjęto, że Prokurator Generalny oraz kierownicy jednostek organizacyjnych prokuratury moga przekazywać mediom informacje z toczącego się postępowania przygotowawczego, z wyłączeniem informacji niejawnych, mając na uwadze ważny interes publiczny. Przyjęte rozwiązanie sprowadza duże niebezpieczeństwo zbyt częstego naruszenia sfery prywatnej osób włączonych do prowadzonego postępowania, jeżeli informacje te będa przekazywane $\mathrm{w}$ fazie in personam postępowania przygotowawczego, a w odniesieniu do przestępstw, które rodzajowo zdeterminowane sa przez osobę sprawcy, zagrożenie to może nastapić już w fazie postępowania in rem. Trzeba bowiem podkreślić, że nawet przedstawienie zarzutu nie przesądza jeszcze o możliwości wniesienia skargi do sądu, a więc przedwczesne upublicznianie danych podejrzanego poza okolicznościami, w których upublicznienie to jest niezbędne $\mathrm{z}$ uwagi na jego poszukiwania, powinno następować tylko przy rzetelnym interpretowaniu pojęcia interesu publicznego. Warto przy tym zauważyć, że odpowiedzialnościa za powstałe na tym tle roszczenia obciążony został Skarb Państwa (§ 4), przy odpowiednim zastosowaniu przepisów art. 119-121 ustawy z 26 czerwca 1974 r. - Kodeks pracy (Dz. U. 2014, poz. 1502 ze zm. [§5]).

\section{WNIOSKI KOŃCOWE}

Konfrontując zatem, na tle formułowanych przez Komisję Wenecką standardów niezależności prokuratury i prokuratora, rozwiązania zaproponowane w ustawie Prawo o prokuraturze z 2016 r. z rozwiazaniami wypracowanymi wraz z przyjęciem w 2009 r. nowelizacji ustawy o prokuraturze, można stwierdzić, że proponowane zmiany nie podążają w kierunku niezależności.

Wśród istotnych z punktu widzenia Komisji Weneckiej gwarancji, które sprzyjają niezależności prokuratora, w pierwszej kolejności wskazuje się na potrzebę odpolitycznienia prokuratury. Komisja jednoznacznie nie wskazuje instrumentów, za pomoca których stan ten można osiagnąć, ale uważa wybór prokuratora generalnego przez parlament za krok w kierunku upolitycznienia tego urzędu. Połącznie urzędu Prokuratora Generalnego z urzędem Ministra 
Sprawiedliwości, wchodzącego w skład Rady Ministrów, sugeruje, że zabieg ten może przyczynić się do upolitycznienia urzędu Prokuratora Generalnego.

W świetle aprobowanych przez Komisję rozwiązań znajdował się model wypracowany w ramach nowelizacji ustawy o prokuraturze z 2009 r., zgodnie z którym Prokuratora Generalnego powoływał Prezydent na wniosek Krajowej Rady Prokuratorów, na ustawowo ustaloną sześcioletnią kadencję, z formą kontroli poprzez nałożenie na Prokuratora Generalnego obowiązku składania corocznych sprawozdań Prezesowi Rady Ministrów. Według koncepcji przyjętej w Prawie o prokuraturze długość kadencji Prokuratora Generalnego połączona została z długością sprawowania urzędu przez Ministra Sprawiedliwości, która weryfikowana jest w rytmie czteroletnim odpowiadającym terminom wyborów parlamentarnych.

W ocenie Komisji Europejskiej w realizacji standardu niezależności prokuratora ważną rolę pełni Rada Prokuratorów. W tym kontekście trzeba zauważyć, że wyłącznie Krajowej Rady Prokuratorów z procedury powoływania Prokuratora Generalnego przyczynia się do obniżenia gwarancji niezależności prokuratury i prokuratorów.

Reaktywowanie unii personalnej między Ministrem Sprawiedliwości i Prokuratorem Generalnym modyfikuje też spojrzenie na zasadę odpowiedzialności, którą w ocenie Komisji Weneckiej skutecznie kontroluje obowiązek składania corocznych sprawozdań z działalności Prokuratora Generalnego rządowi lub parlamentowi, połączony z możliwością w razie odrzucenia sprawozdania, wnioskowania o odwołanie Prokuratora Generalnego. Unia personalna między Ministrem Sprawiedliwości a Prokuratorem Generalnym doprowadziła do wyeliminowania obowiązku składania sprawozdań, jaki na urzędującego niezależnie Prokuratora Generalnego nałożyła ustawa o prokuraturze w wersji nadanej nowelizacją z 2009 r. ${ }^{21}$, co wyklucza tę formę kontroli, z uwagi utratę niezależności Prokuratora Generalnego i włącznie go w nurt władzy wykonawczej.

Wreszcie mając na uwadze określenie granic niezależności prokuratora, trzeba zauważyć, że granice te zostały wyraźnie zawężone przez przywrócenie możliwości wydawania przez przełożonych wobec prokuratora dokonującego czynności poleceń ingerujących w treść czynności procesowej, co wyłącza możliwość niezależnego prowadzenia postępowania i otwiera przełożonym, łącznie z Prokuratorem Generalnym, szerokie możliwości ingerowania w konkretne sprawy.

dr hab. Anna Gerecka-Żotyńska

Profesor Uniwersytetu im. Adama Mickiewicza w Poznaniu gerecka@amu.edu.pl

${ }^{21}$ Ustawa - Prawo o prokuraturze nakłada na Prokuratora Generalnego, jedynie obowiązek przedstawiania Sejmowi i Senatowi informacji związanych z zarządzeniem kontroli i utrwalania rozmów oraz kontroli operacyjnej (art. $11 \S 1$ Prawa o prokuraturze). 


\section{INDEPENDENCE OF PROSECUTORS AND THE PUBLIC PROSECUTOR'S OFFICE - NEW SOLUTIONS AGAINST THE BACKGROUND OF THE CURRENT CONTROVERSIES (SOME REMARKS ON THE ACT OF 28 JANUARY 2016 - LAW ON THE PUBLIC PROSECUTOR'S OFFICE)}

\section{Sum mary}

The functioning in practice of the independence of the public prosecutor's office and individual prosecutors in Poland has been examined. First, the solutions adopted upon completion of the Round Table discussion are presented, taking into consideration the constitutional provisions then adopted. Next the European standards approved by European organisations and in particular the Committee of Ministers of the Council of Europe and the Venice Commission regarding assurance of the independence of the judiciary are discussed and confronted with the statutory solutions that have till date applied in Poland.

A fair assessment of the functioning and the regime of the public prosecutor's office has been made in the context of the implementation of the amendments of 2009 to the law on the public prosecutor's office, showing that no further amendments to, or changes in the existing status quo are necessary. In the third part of the paper, the recent provisions adopted directly with regards to the independence of prosecutors and the public prosecutor's office are presented, although their actual assessment will only be possible once the new law has come into force. 